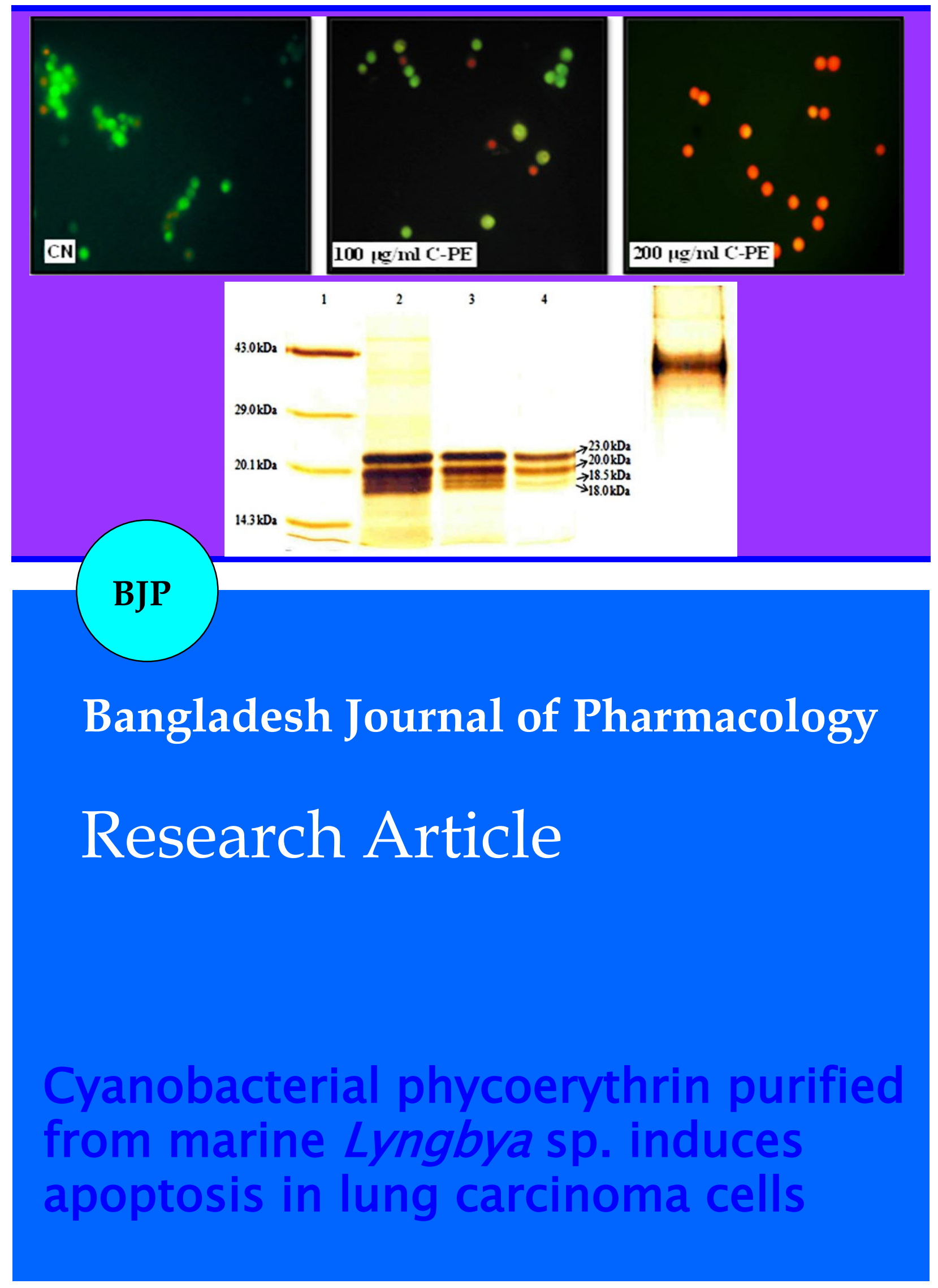




\title{
Cyanobacterial phycoerythrin purified from marine Lyngbya sp. induces apoptosis in lung carcinoma cells
}

\author{
Datta Madamwar'1, Avani Kaushal', Dipak K. Patel3, Swati N. Desai², Kapil Upadhyay² and \\ Ranjitsinh V. Devkar²
}

${ }^{1}$ BRD School of Biosciences, Sardar Patel Maidan, Vadtal Road, Satellite Campus, Post Box No. 39, Sardar Patel University, Vallabh Vidyanagar 388 120, Anand, Gujarat, India; ${ }^{2}$ Division of Phytotherapeutics and Metabolic Endocrinology, Department of Zoology, Faculty of Science, The Maharaja Sayajirao University of Baroda, Vadodara 390 002, Gujarat, India; ${ }^{3}$ Ecotoxicology Lab, Jai Research Foundation, Vapi, Gujarat, India.

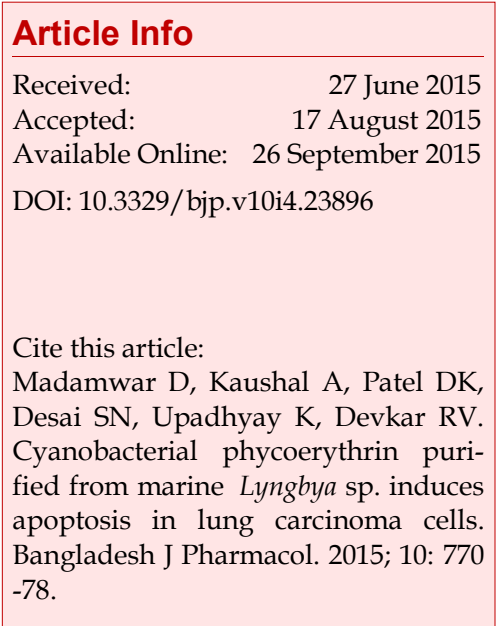

\begin{abstract}
Phycoerythrins from various cyanobacterial sources have been extensively studied globally for their therapeutic potentials. This study shows the apoptotic potential of cyanobacterial phycoerythrin isolated, purified and characterized from marine Lyngbya sp. A09DM on human lung carcinoma cells (A549 cell). Results indicated that purified cyanobacterial phycoerythrin accounted for a dose-dependent decrement in cell viability, mitochondrial membrane potential and an increment in lactate dehydrogenase release. Higher dose of cyanobacterial phycoerythrin caused loss of cell viability and nuclear condensation/fragmentation. Flow cytometry accounted for more number of cells in $\mathrm{G}_{0} / \mathrm{G}_{1}$ phase and an increase in total number of early apoptotic cells $(39.5 \%)$. Overall, this study is the first to report on apoptotic property of cyanobacterial phycoerythrin from marine Lyngbya sp. A09DM against A549 human lung carcinoma cells and requires a detailed scrutiny to establish its anti-cancer potential.
\end{abstract}

\section{Introduction}

Lung cancer accounts for about $17 \%$ of the newly reported cases of cancer and $23 \%$ of the total cancer deaths that occur annually primarily due to nicotine intake and various occupational hazards (Report on carcinogenesis, 2011). Extensive use of chemotherapy for alleviating symptoms and for treating lung cancer also involves undesired physiological effects. In recent times, metal complexes (Singh et al., 2012; Vyas et al., 2013; Vyas et al., 2014; Ramadevi et al., 2015; Thakore et al., 2015), herbal extracts (Sankhari et al., 2012; Patel et al., 2012), structured nano sized particles (Valodkar et al., 2011; Valodkar et al., 2012) or novel proteins from bacterial or fungal origins (Huang et al., 2002) have been extensively researched as a therapeutic option.
Phycobiliproteins are light-harvesting accessory pigments with immunomodulatory, anti-inflammatory, anti-oxidant and nutritional properties (Belay, 2002; Rodríguez-Sánchez et al., 2012). Cyanobacterial phycoerythrin (absorption- 520 to $580 \mathrm{~nm}$ and emission peak at $575 \pm 10 \mathrm{~nm}$ ) is used as a dietary supplement (Romay et al., 2003) that also inhibits growth of tumor cells (Huang et al., 2002; Pan et al., 2013; Madamwar et al., 2015). However, cytotoxic property of proteins from a marine cyanobacteria Lyngbya sp. against carcinoma cells has so far not been reported.

This study investigates the impact of cyanobacterial phycoerythrin on A549 lung carcinoma cells wherein, alterations in cell morphology, cell cycle and possible induction of apoptosis has been scrutinized in detail. 


\section{Materials and Methods}

\section{Chemicals}

Sephadex G-150 powdered matrix (bead-diameter 20$300 \mu \mathrm{m}$ and fractionation range $5-300 \mathrm{kDa}$ ) was purchased from GE Healthcare UK Limited (UK), 2, 4, 6tripyridyl-s-triazine and ferric chloride (hexahydrate) from Sigma, USA; protein molecular mass standard from Bangalore Genei (India); sodium dodecyl sulfate, electrophoresis grade acrylamide and bisacrylamide from Merck (Germany). Phosphate buffer saline, Dulbeco's Modified Eagle Medium, trypsin phosphate versene glucose solution, trypsin and methylthiazolyldiphenyltetrazolium bromide (MTT) were purchased from HiMedia Laboratories Pvt. Ltd. (India). Fetal bovine serum was purchased from Biosera (UK) and dimethyl sulfoxide was purchased from the Sisco Research Laboratories Pvt. Ltd. (India).

\section{Isolation and growth condition}

The enrichment, isolation and purification of the cyanobacterial cell culture were carried out according to Shah et al. (2001). Samples were isolated from the rocky shores of Bet Dwarka, Okha and estuarine mouth of river Daman Ganga and further cultivated in ASN III medium (Waterbury and Stanier, 1981) with 12:12 light:dark (L:D) cycles at $27 \pm 2{ }^{\circ} \mathrm{C}$ and illumination of 36 $\mathrm{W}$ white fluorescent lamps at a flux density of $130 \mu \mathrm{mol}$ photons.m- ${ }^{-2} \cdot \mathrm{sec}^{-1}$. Identification by 16S-rRNA gene sequencing showed that the isolated strain was Lyngbya sp. A09DM (accession number: HM446280).

\section{Extraction}

Marine Lyngbya sp. A09DM culture was harvested within 30 days of inoculation (Soni et al., 2006). Cyanobacterial cell mass was washed with $1 \mathrm{M}$ Tris $\mathrm{Cl}$ buffer ( $\mathrm{pH} 8.1$ ) containing $3 \mathrm{mM}$ sodium azide. One volume of washed cell mass was resuspended in five volumes of the same buffer and subjected to repeat freeze-thaw cycles of $-30^{\circ} \mathrm{C}$ and $4^{\circ} \mathrm{C}$ shocks for the release of phycobiliprotein. The cell debris was removed by centrifugation at 17,000 xg (Kubota 6500, Bunkyo$\mathrm{Ku}$, Tokyo, Japan) for $40 \mathrm{~min}$ and the supernatant was termed as crude extract.

\section{Purification}

Steps of purification were carried out as described by Parmar et al., (2011).

\section{Ammonium sulfate precipitation}

The crude extract was subjected to two step ammonium sulfate precipitation (20\% and $70 \%$ ) followed by centrifugation at $15,000 \mathrm{xg}$ for $40 \mathrm{~min}$ at $4^{\circ} \mathrm{C}$. The supernatant were discarded and the pellet was resuspended in 10 $\mathrm{mM}$ Tris $\mathrm{Cl}$ buffer ( $\mathrm{pH} 8.1$ ). The extracts, thus, obtained were termed as $70 \%$ ammonium sulfate cut that was further subjected to dialysis for 24 hours against 100 times volume of MilliQ water containing $3 \mathrm{mM}$ sodium azide.

\section{Gel permeation chromatography}

Dialysed $70 \%$ ammonium sulfate cut was applied on a sephadex G-150 column (45 cm x $1.5 \mathrm{~cm}$, bed height 35 $\mathrm{cm})$ pre-equilibrated and eluted with $10 \mathrm{mM}$ Tris $\mathrm{Cl}$ buffer ( $\mathrm{pH}$ 8.1). The flow rate was maintained at 60 $\mathrm{mL}$ /hour using peristaltic pump (Model P1; Pharmacia, Sweden). Bright pink color elutes were collected as 1 $\mathrm{mL}$ fractions.

\section{Biochemical estimations and characterization of protein}

The protein contents were determined by the method of Lowry et al., (1951) with bovine serum albumin as the standard. Phycoerythrin from all the three steps- crude, dialyzed $70 \%$ ammonium sulfate cut and gel permeation chromatography elutes were characterized by UVVisible spectrophotometer (Analytik Jena AG Specord ${ }^{\circledR}$ 210, Germany). The amount of cyanobacterial phycoerythrin, cyanobacterial phycocyanin, and cyanobacterial allophycocyanin was calculated according to equations of Bennett and Bogorad (1973). The ferric reducing ability of plasma assay was performed according to Benzie and Strain (1996). A fresh cocktail solution was prepared by mixing solution A $(300 \mu \mathrm{M}$ acetate buffer- pH 3.6), solution B (10 mM TPTZ 2, 4, 6tripyridyl-s-triazine prepared in $40 \mathrm{mM}$ hydrochloric acid) and solution C (20 mM ferric chloride hexahydrate) at a ratio of 10:1:1. Later, $30 \mu \mathrm{L}$ sample and 90 $\mu \mathrm{L}$ distilled water was added to $900 \mu \mathrm{L}$ of cocktail solution and the mixture was incubated at $37^{\circ} \mathrm{C}$ for 4 min. Absorbance was read at $593 \mathrm{~nm}$ and was recorded against a reagent blank. The purified phycoerythrin was also characterized in terms of the molecular masses of the subunits. Non-denaturing and denaturing polyacrylamide gel electrophoresis was carried out using $15 \%$ polyacrylamide slab gels (Singh et al., 2009) and the same was visualized by silver staining (Garfin, 1990). For calibration, marker proteins ranging from 6 $\mathrm{kDa}$ to $43 \mathrm{kDa}$ (aprotinin- $6 \mathrm{kDa}$, lysozyme- $14.3 \mathrm{kDa}$, soyabean trypsin inhibitor- $20.1 \mathrm{kDa}$, carbonic anhydrase- $29 \mathrm{kDa}$ and ovalbumin- $43 \mathrm{kDa}$ ) were used. Bilin chromophore was detected using zinc-acetate staining as per Brekelman and Lagarias (1986), and the bilin fluorescence was observed under UV light using AlphaEase FC Imaging System (Alpha Innotech Corp., USA).

\section{Cell line and culture}

Human lung carcinoma (A549) cells were obtained from National Centre for Cell Science, Pune, India and were seeded ( $1 \times 10^{5}$ cells/T25 flask) and cultured in Dulbeco's Modified Eagle Medium containing 10\% fetal bovine serum and $1 \%$ antibiotic-antimycotic solution at $37^{\circ} \mathrm{C}$ with $5 \%$ in water jacketed $\mathrm{CO}_{2}$ incubator (Thermo 
scientific, forma series II 3111, USA). Cells were subcultured every third day by trypsinization with trypsin phosphate versene glucose solution. Reagents used herein were filtered through $0.22 \mu$ filter (Millipore Biomedical Aids Pvt. Ltd, Pune) prior to their use for the experiment. A549 cells were maintained for a period of 24 hours in absence or presence of phycoerythrin at a cell density of $5.0 \times 10^{3}$ cells/well in 96 well plate for MTT and LDH assay and $1 \times 10^{5}$ cells/well in 6 well plate for other assays mentioned herein.

\section{Cell viability assay}

A549 cells ( $7 \times 10^{3}$ cells/well) were maintained in 96well culture plates (Tarson India Pvt. Ltd.) for 24 hours with or without phycoerythrin $(10,25,50,100,200 \mu \mathrm{g} /$ $\mathrm{mL})$. Later, $10 \mu \mathrm{L}$ of 3-(4,5-dimethylthiazol-2-yl)-2,5diphenyl-tetrazolium bromide (MTT, $5 \mathrm{mg} / \mathrm{mL}$ ) was added to the wells and plates were incubated at $37^{\circ} \mathrm{C}$ for 4 hours. Subsequently, the culture media were discarded and wells were washed with phosphate buffered saline. The resultant formazan formed was dissolved in $150 \mu \mathrm{L}$ of DMSO and absorbance was read at $540 \mathrm{~nm}$ in BIOTEK ELX800 Universal Microplate Reader (USA).

\section{LDH release assay}

Cellular integrity of A549 cells was measured with LDH release assay, wherein cells were maintained in 96 well plates with or without phycoerythrin for 24 hours as mentioned above. Later, supernatant from each well was collected and LDH was assayed with commercially available kit (Reckon diagnostics Ltd., India) on Merck microlab L 300 semi-autoanalyzer (India). Based upon the readings obtained, percentage cytotoxicity was calculated.

\section{Intracellular oxidative stress}

Intracelluar oxidative stress due to reactive oxygen species generation in A549 cells was studied using 2,7dichlorodihydrofluoroscein diacetate (CM- $\left.\mathrm{H}_{2}-\mathrm{DCFDA}\right)$ staining. Cells were treated with cyanobacterial phycoerythrin for 18 hours as per the method mentioned above. Later, the cells were incubated with $7.5 \mu \mathrm{M}$ DCFDA at $37^{\circ} \mathrm{C}$ for $30 \mathrm{~min}$ and cells were photographed in Leica DMRB fluorescent microscope (Germany) using Canon Power Shot camera.

\section{Mitochondrial membrane potential}

The changes in mitochondrial membrane potential were measured using the fluorescent cationic dye rhodamine 123 (RHO 123). A549 cells were incubated for 24 hours with or without cyanobacterial phycoerythrin as mentioned above. Later, cells were incubated with $1 \mu \mathrm{M}$ RHO 123 for $10 \mathrm{~min}$ at $37^{\circ} \mathrm{C}$ and the fluorescence was determined at an excitation and emission wavelengths of 485 and $530 \mathrm{~nm}$, respectively using spectroflurometer (Jasco FP-6300, Japan) and expressed as fluorescence intensity units.

\section{Assessment of cyanobacterial phycoerythrin-induced cell cycle analysis and apoptosis}

Assessment of nuclear morphology was done using DAPI staining. A549 cells $\left(5 \times 10^{4}\right.$ cells/well $)$ were plated into 6-well plate. After $80 \%$ confluence was achieved, the cells were treated with or without different concentrations of cyanobacterial phycoerythrin at $37^{\circ} \mathrm{C}$ for 24 hours. Single-cell suspensions of treated cells were washed with phosphate buffered saline and fixed with $70 \%$ ethanol for $20 \mathrm{~min}$ at room temperature. Cells were re-washed with phosphate buffered saline and stained with DAPI $(0.6 \mu \mathrm{g} / \mathrm{mL}$ in phosphate buffered saline) for $5 \mathrm{~min}$. Nuclear morphology (condensed/ fragmented nuclei) was examined under Leica DMRB fluorescence microscope (Germany).

Apoptotic cells were studied using AO/EB staining. A549 cells ( 1 × $10^{5}$ cells/well) were maintained in 6 well plates for 24 hours with or without cyanobacterial phycoerythrin as described earlier. At the end of experiment period, cells were collected using TPVG solution. One microliter of dye mixture $(1 \mathrm{mg} / \mathrm{mL} \mathrm{AO}$ and $1 \mathrm{mg} / \mathrm{mL}$ EB in phosphate buffered saline) was mixed with $9 \mu \mathrm{L}$ of cell suspension $\left(0.5 \times 10^{6}\right.$ cells $\left./ \mathrm{mL}\right)$ on a clean microscope slide and examined and photographed under Leica DMRB fluorescence microscope (Germany). A minimum of 300 cells were counted in every sample to calculate percentage cell death.

Cells $\left(1 \times 10^{6}\right.$ cells/well $)$ were cultured with or without phycoerythrin as mentioned earlier for 24 hours. After incubation, the cells were washed once in ice-cold phosphate buffered saline and subjected to cell cycle analysis. Briefly, $1 \times 10^{5}$ cells were fixed in $4.5 \mathrm{~mL}$ of $70 \%(\mathrm{v} / \mathrm{v}$ ) cold ethanol for $30 \mathrm{~min}$, centrifuged at $400 \mathrm{xg}$ for $5 \mathrm{~min}$. Supernatant was removed and cells were washed with $5 \mathrm{~mL}$ of phosphate buffered saline. Cells were then re-suspended in $0.5 \mathrm{~mL}$ of phosphate buffered saline and $0.5 \mathrm{~mL}$ of DNA extraction buffer (Mix $192 \mathrm{~mL}$ of $0.2 \mathrm{M} \mathrm{Na}_{2} \mathrm{HPO}_{4}$ with $8 \mathrm{~mL}$ of $0.1 \%$ Triton $\mathrm{X}-100 \mathrm{v} / \mathrm{v}$ ) was added. The $\mathrm{pH}$ was adjusted to 7.8. Cells were incubated at room temperature for $5 \mathrm{~min}$ and then centrifuged at $400 \mathrm{xg}$ for $5 \mathrm{~min}$. Supernatant was discarded and cells were re-suspended in $1 \mathrm{~mL}$ of DNA staining solution $(200 \mathrm{mg}$ of PI in $10 \mathrm{~mL}$ of phosphate buffered saline $+2 \mathrm{mg}$ of DNase free RNase). Cells are then incubated for at least $30 \mathrm{~min}$ at room temperature in the dark and the cell cycle distribution was then analyzed on a flow cytometer (BD FACS Aria III, USA) using FlowJo (Oregon, USA).

Annexin $\mathrm{V} /$ propidium iodide double staining assay was used to quantify apoptosis, according to the manufacturer's protocol (Alexa Fluor 488 annexin V/ dead cell apoptosis kit, Invitrogen). After incubation, cells were harvested using TPVG solution and washed with ice-cold phosphate buffered saline and suspended 
in $100 \mu \mathrm{L}$ of $1 \mathrm{x}$ binding buffer $(10 \mathrm{mM}$ HEPES, $140 \mathrm{mM}$ $\mathrm{NaCl}$, and $2.5 \mathrm{mM} \mathrm{CaCl}_{2}, \mathrm{pH} 7.4$ ). To this mixture, $5 \mu \mathrm{L}$ of annexin V-Alexa Fluor 488 conjugate and $1 \mu \mathrm{L}$ of propidium iodide solution were added to each cell suspension and incubated for $15 \mathrm{~min}$ at room temperature in the dark. Samples were analyzed on flow cytometer (BD FACSAria III, USA) using FlowJo (Oregon, USA). Double staining of cells with Alexa Fluor 488 annexin-V and propidium iodide enables the discrimination of live cells (Alexa Fluor 488-PI-), early apoptotic (Alexa Fluor $488^{+} \mathrm{PI}-$ ), late apoptotic (Alexa Fluor $488^{+} \mathrm{PI}^{+}$) or necrotic cells (Alexa Fluor 488-PI+ ${ }^{+}$.

\section{Statistical analysis}

Data was analyzed for statistical significance using one way analysis of variance (ANOVA) followed by Bonferroni's multiple comparison test and results were expressed as mean \pm SEM using Graph Pad Prism version 3.0 for Windows, Graph Pad Software, San Diego, California, USA.

\section{Results}

Precipitation of cyanobacterial phycoerythrin could not be achieved in first step because the supernatant of $20 \%$ ammonium sulfate cut in $70 \%$ ammonium sulfate was not efficient for its extraction. Hence, in the second step, the contents were dialyzed overnight and precipitate of cyanobacterial phycoerythrin with a purity ratio of 1.66 was obtained. In the final step, fractionation of the resultant cyanobacterial phycoerythrin was done with sephadex G-150 to achieve a purity ratio of 3.67 and a final yield of $65.2 \%$. The purity of cyanobacterial phycoerythrin was monitored at each step by UVVisible spectroscopy and gel electrophoresis. The purity ratio was monitored at each step by overlay spectra using UV-Visible spectroscopy. The absorbance maxima $\left(\lambda_{\max }\right)$ for phycoerythrin was recorded at $562 \mathrm{~nm}$. The purity ratios of phycoerythrin to total protein $\left(A_{562} / A_{280}\right)$, phycoerythrin to phycocyanin $\left(A_{562} / A_{620}\right)$, and phycoerythrin to allophycocyanin $\left(A_{562} / A_{650}\right)$ were $3.57,4.09$ and 11.41, respectively (Table I).

Non-denaturing gel electrophoresis of purified cyanobacterial phycoerythrin showed two bands corresponding to phycoerythrin-I and phycoerythrin-II, suggesting homogeneity of purified cyanobacterial phycoerythrin (Figure 1a). Denaturing gel electrophoresis of cyanobacterial phycoerythrin showed the presence of four bands having molecular masses of 23, 20, 18.5 and $18 \mathrm{kDa}$ (Figure 1b). These bands were

Table I

Determination of spectophotometric purity and concentration of phycobiliproteins

\begin{tabular}{|lcccccccccc|}
\hline Purification stages & $\begin{array}{c}A_{562} \\
(\mathrm{~nm})\end{array}$ & $\begin{array}{c}A_{620} \\
(\mathrm{~nm})\end{array}$ & $\begin{array}{c}A_{650} \\
(\mathrm{~nm})\end{array}$ & $\begin{array}{c}A_{562} / \\
A_{280}\end{array}$ & $\begin{array}{c}A_{562} / \\
A_{620}\end{array}$ & $\begin{array}{c}A_{562} / \\
A_{650}\end{array}$ & $\begin{array}{c}\text { C-PE } \\
(\mathrm{mg} / \mathrm{mL})\end{array}$ & $\begin{array}{c}\text { C-PC } \\
(\mathrm{mg} / \mathrm{mL})\end{array}$ & $\begin{array}{c}\text { C-APC } \\
(\mathrm{mg} / \mathrm{mL})\end{array}$ & $\begin{array}{c}\text { Total protein } \\
(\mathrm{mg})\end{array}$ \\
\hline Crude extract & 0.31 & 0.06 & 0.01 & 0.81 & 5.33 & 36.83 & 0.03 & 0.01 & -0.01 & 13.21 \\
$\begin{array}{l}\text { Dialyzed 70\% am- } \\
\text { monium sulfate cut }\end{array}$ & 0.45 & 0.14 & 0.07 & 1.66 & 3.25 & 6.33 & 0.03 & 0.02 & 0.01 & 10.74 \\
$\begin{array}{l}\text { Gel permeation } \\
\text { chromatography }\end{array}$ & 0.70 & 0.17 & 0.06 & 3.57 & 4.09 & 11.41 & 0.06 & 0.03 & 0.01 & 8.61 \\
\hline
\end{tabular}

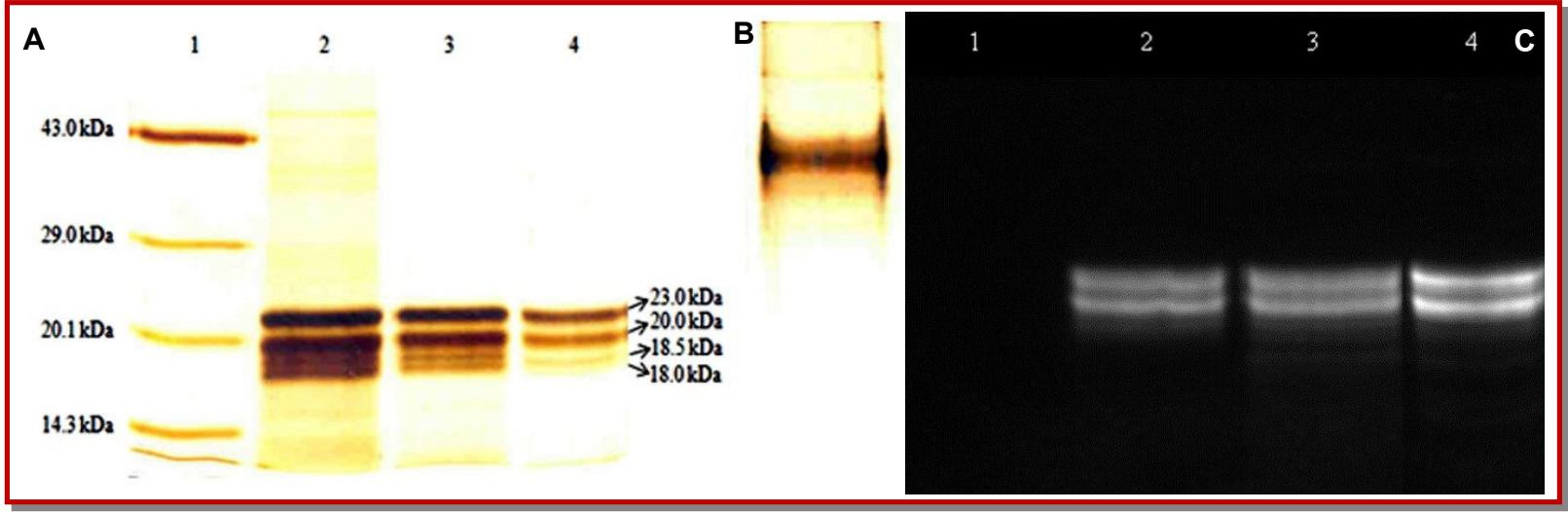

Figure 1: Detection of proteins by silver staining (A) and biliproteins by zinc-assisted fluorescence enhancement method (C). Lanes in (A) and (C): 1. Protein molecular mass marker; 2. Crude extract; 3. Ammonium sulfate cut (70\%); 4. Pure PE eluate from gel permeation chromatography. Molecular mass marker had no biliproteins and hence, no fluorescence was detected. $5 \mathrm{mg}$ protein was loaded in each lane. (B) Silver stained $12 \%$ native gel electrophoresis of purified cyanobacterial phycoerythrin from Lyngbya sp. A09DM 


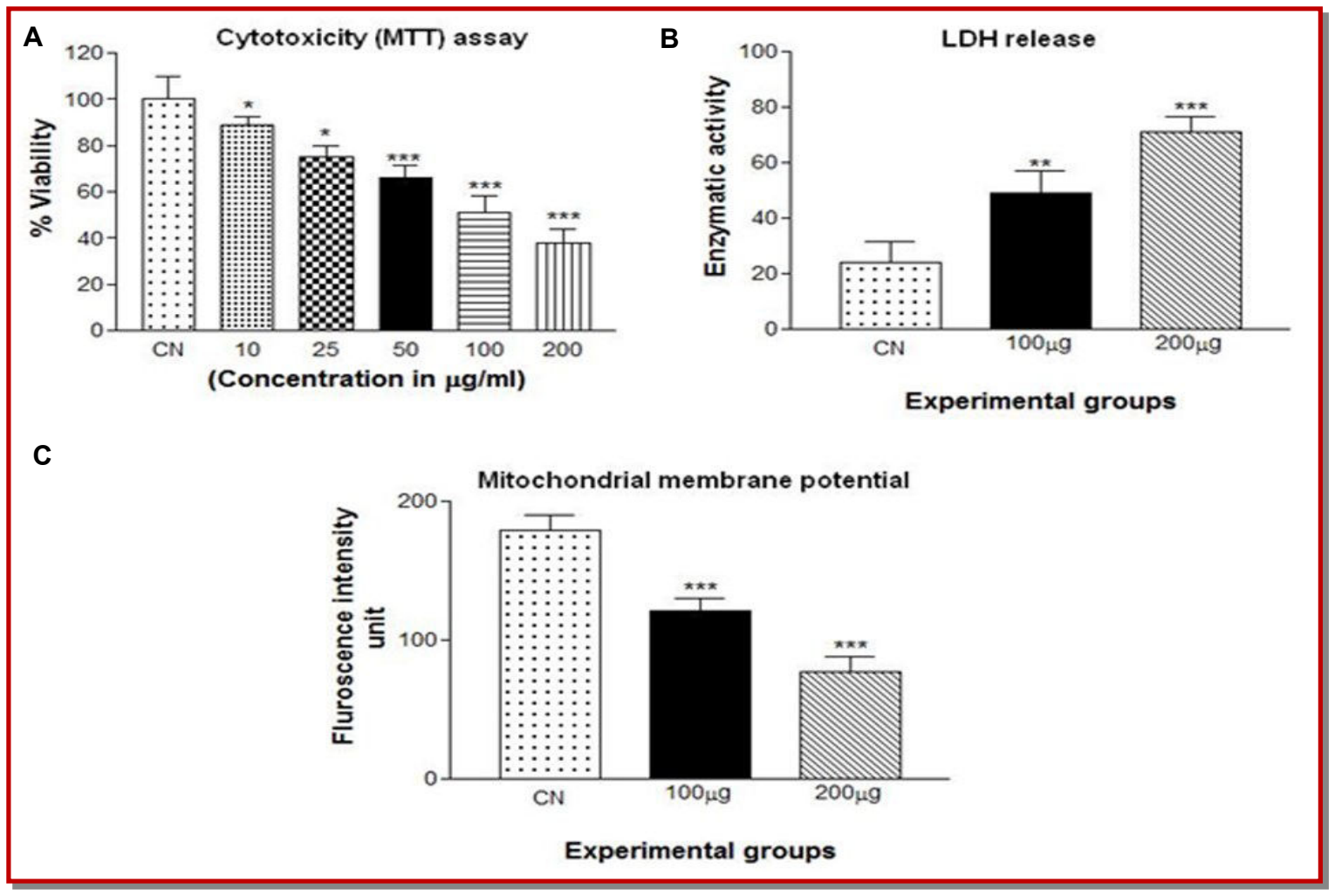

Figure 2: (A) Cytotoxicity assay of A549 cells following 24 hours cyanobacterial phycoerythrin treatment. (B) LDH release from untreated cells and 24 hours cyanobacterial phycoerythrin treated cells. (C) Mitochondrial membrane potential of untreated and 24 hours cyanobacterial phycoerythrin treated cells. ${ }^{*} \mathrm{p}<0.05 ;{ }^{* *} \mathrm{p}<0.01 ;{ }^{* * *} \mathrm{p}<0.001$

obtained in the last step of purification and corresponded to $\alpha$ and $\beta$ subunits of each of phycoerythrin-I and phycoerythrin-II. The presence of bilin chromophore group attached to the phycoerythrin subunit was confirmed by zinc-acetate staining that showed characteristic orange fluorescence under UV light. No fluorescence was observed in molecular mass standard due to the absence of bilin-linked peptides. These results also confirmed attachment of bilin chromophore groups to the subunits of phycoerythrin (Figure 1c).

The antioxidant capacity of purified cyanobacterial phycoerythrin obtained herein was $48.45 \mu \mathrm{m}$ AEAC as per the results obtained in FRAP assay. Cytotoxic potential of cyanobacterial phycoerythrin against lung carcinoma cell line is shown in (Figure 2a). Cells treated with cyanobacterial phycoerythrin showed a dose dependent inhibitory effect. Also, there was a significant dose dependent increment in LDH release following cyanobacterial phycoerythrin treatment as compared to untreated control cells (Figure 2b). Overall, a maximum cell growth inhibition $(>80 \%)$ and $\mathrm{LDH}$ release was recorded at $200 \mu \mathrm{g} / \mathrm{mL}$ dose of cyanobacterial phycoerythrin.

The fluorimetric analysis of cyanobacterial phycoerythrin treated samples recorded a dose-dependent decrement in MMP as compared to untreated group.
The lowest MMP was recorded in $200 \mu \mathrm{g} / \mathrm{mL}$ dose of phycoerythrin (Figure 2c).

The apoptosis induced by phycobiliprotein in A549 cells was confirmed by $\mathrm{AO} / \mathrm{EtBr}$ staining. The cells of untreated control group showed green fluorescence indicating viability whereas, these cells were progressively less in number in a dose-dependent manner in phycoerythrin-treated group. More number of yellow colored cells was present in $100 \mu \mathrm{g} / \mathrm{mL}$ phycoerythrintreated group. The same indicates the early apoptotic stage. However, $200 \mu \mathrm{g} / \mathrm{mL}$ phycoerythrin-treated group showed more number of reddish or orange stained cells that symbolize late apoptotic phase (Figure 3a). DAPI staining phycoerythrin-treated cells showed higher number of cells with condensed nuclei in phycoerythrin-treated groups as compared to control group (Figure 3b). The cell cycle analysis (Figure 4a) showed $93.1 \%$ in $\mathrm{G}_{0} / \mathrm{G}_{1}$ and $4.5 \%$ of cells in sub $\mathrm{G}_{0} / \mathrm{G}_{1}$ phase in control group whereas, $15 \%$ in $\mathrm{G}_{0} / \mathrm{G}_{1}$ and $83.3 \%$ of cells in sub $G_{0} / G_{1}$ phase in phycoerythrintreated group. Flow cytometric assay with annexin V/ propidium iodide double staining of control and phycoerythrin-treated cells showed that apoptosis rate was increased after phycoerythrin-treatment as they recorded $39.5 \%$ annexin $\mathrm{V}$ positive (early apoptotic) and $0.51 \%$ annexin $\mathrm{V}$ and propidium iodide positive cells (late apoptotic) compared to $0.9 \%$ and $0.6 \%$ in control 


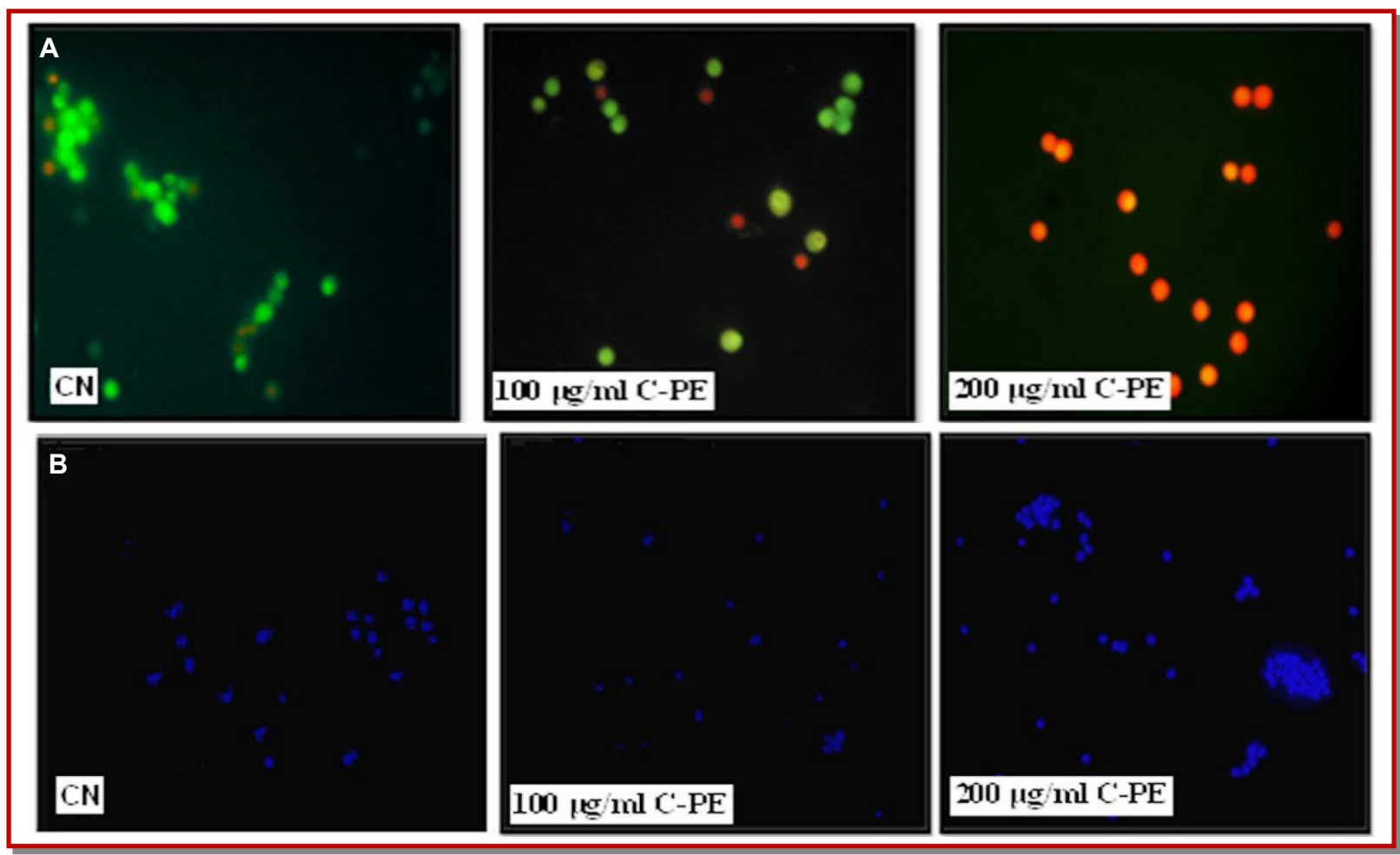

Figure 3: (A) AO and EB stained A549 cells; CN-untreated cells, 100 and $200 \mu \mathrm{g}$ cyanobacterial phycoerythrin treated with low and high doses respectively. Yellow or orange fluorescence indicates nonviable cells. (B) DAPI stained CN-untreated cells, 100 or $200 \mu \mathrm{g}$ cyanobacterial phycoerythrin-treated with low and high doses respectively

group (Figure $4 b$ ).

\section{Discussion}

This study elaborates the method of purification of phycoerythrin from a novel isolate Lyngbya sp. A09DM and its subsequent cytotoxicity against A549 lung carcinoma cells. Culturing of Lyngbya sp. under white light can be considered as an efficient source for obtaining cyanobacterial phycoerythrin with a high purity ratio of 3.67. Also, the two-step ammonium sulfate precipitation method is equally efficient for purification of cyanobacterial phycoerythrin and these results are in agreement with Rito-Palomares et al., (2001). Cytotoxicity (MTT) assay of cells treated with cyanobacterial phycoerythrin indicated a dosedependent impact on cell viability wherein, higher dose (200 $\mathrm{\mu g} / \mathrm{mL}$ ) was most potent and accounted for maximum cell growth inhibition (>80\%). Transmembrane potential of mitochondria is an important parameter to assess mitochondrial function and overall health of cell (Patel et al., 2013; Gajaria et al., 2015). In the present study, a dose-dependent decrement in mitochondrial membrane potential was recorded following cyanobacterial phycoerythrin treatment suggesting possible mitochondrial dysfunction. These results provide supportive evidence on cyanobacterial phycoerythrin-induced cytotoxicity recorded in the
MTT assay. Any damage to the plasma membrane of an animal cell causes leaching out of LDH from cytoplasm into the media and the same is measured as an indication of the extant of cell damage (Devkar et al., 2012). Hence, biochemical estimation of $\mathrm{LDH}$ is a reliable and popularly used parameter to assess cell damage. In our study, high levels of LDH are in support of the results obtained in cytotoxicity (MTT) assay.

Experiments with natural anticancer agents have reported that heightened intracellular oxidative stress also accounts for cell death by causing damage to the plasma membrane (Gajaria et al., 2015). But in our study, the control and treated cells showed comparable levels of weak fluorescence suggesting that the cyanobacterial phycoerythrin failed to initiate oxidative stress in A549 cells. At this stage, it was assumed that, cyanobacterial phycoerythrin induced cell death was possibly due to the trigger of apoptotic pathway. Inhibition of a tumor due to the arrest of cell division or cytotoxicity and subsequent induction of apoptotic cell death are key features for treating any type of cancer. The down-stream pathway of apoptotic cascade is reportedly triggered in presence of cytochrome $c$ that leaches out from the transitional pores of mitochondrial membrane (Jiang and Wang, 2004). This event results due to an altered mitochondrial membrane potential as observed in our study. Also, presence of more number 


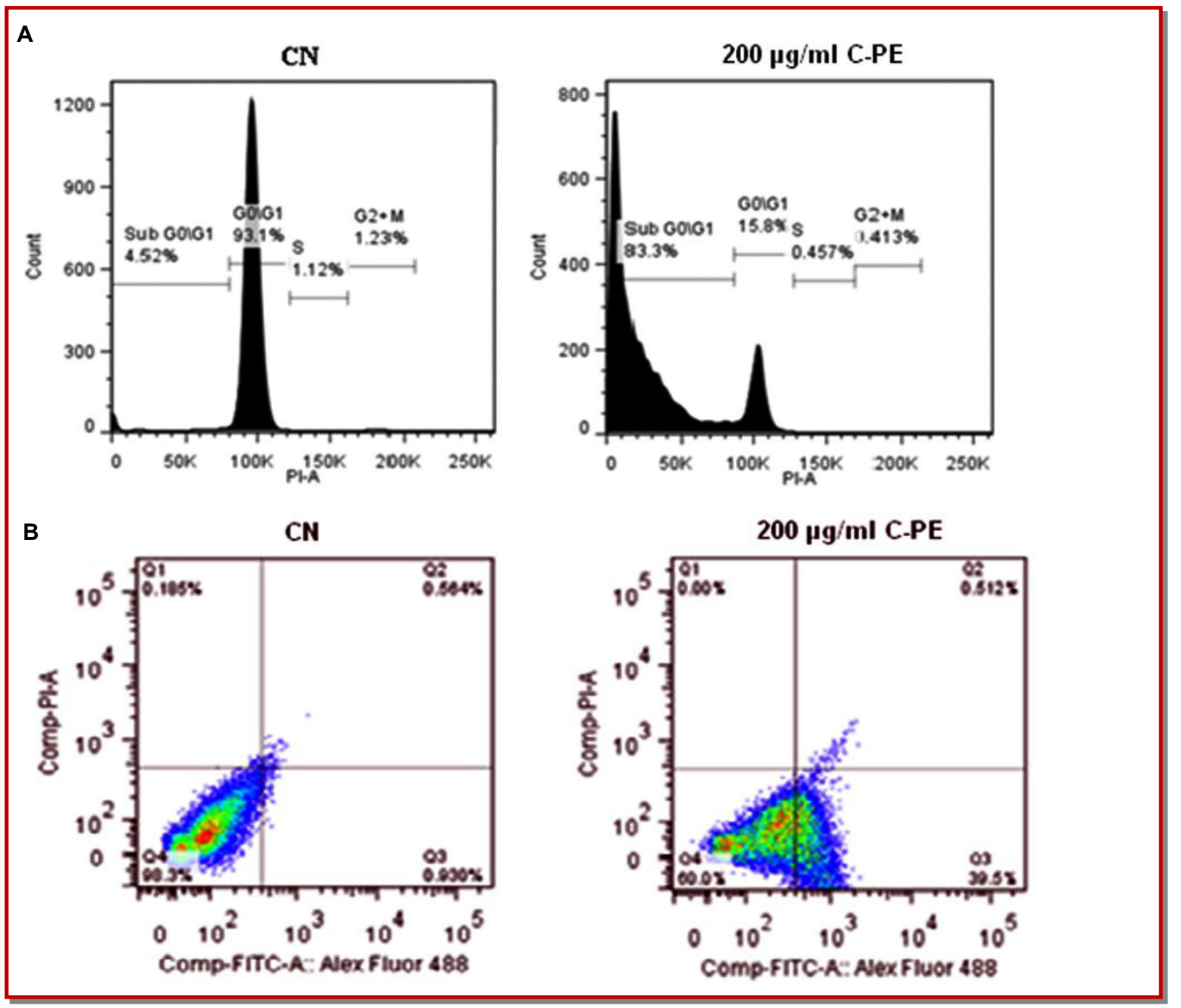

Figure 4: (A) FACS analyses of A549 cells indicate more number of cells in sub G0/G1 phase (83.3\%) following cyanobacterial phycoerythrin treatment as compared to untreated cells (4.52\%). (B) Annexin V-FITC/PI apoptosis detection assay shows higher number of apoptotic cells in cyanobacterial phycoerythrin treated group. CN- Untreated; $200 \mu \mathrm{g} / \mathrm{mL}$ cyanobacterial phycoerythrin high dose

of EB positive cells (red/orange) observed herein, further corroborate the findings that cyanobacterial phycoerythrin is instrumental in inducing cytotoxicity. As compared to the lower dose $(100 \mu \mathrm{g} / \mathrm{mL})$, the higher dose $(200 \mu \mathrm{g} / \mathrm{mL})$ showed qualitative evidence of higher extent of cell damage in form nuclear fragmentation with possible indications of an early apoptosis (Figure 4a). Chromatin condensation, nuclear fragmentation, nuclear shrinkage and formation of apoptotic bodies are characteristic features of apoptosis (Elmore, 2007). Hence, higher dose was chosen for further cell cycle analysis. Flow cytometric analysis revealed that, cyanobacterial phycoerythrin-treated cells showed cell arrest in sub G0/G1 phase $(83.3 \%)$ as compared to the control. Further confirmation of cyanobacterial phycoerythrin-induced apoptosis was obtained with annexin $\mathrm{V}$-propidium iodide staining wherein, a large number of early apoptotic (39.5\%) and only few late apoptotic $(0.51 \%)$ cells were observed. These observations provide compelling evidence on cyanobacterial phycoerythrin induced apoptosis of A549 cells.

\section{Conclusion}

Cyanobacterial phycoerythrin induced altered mitochondrial membrane potential triggers apoptosis in human lung carcinoma cells. This study is the first to report on apoptotic potential of cyanobacterial phycoerythrin from marine Lyngbya sp. A09DM and the findings warrant a detailed scrutiny on its efficacy as an anti-cancer agent.

\section{Conflict of Interest}

The authors declare that they have no competing 
interests.

\section{Acknowledgement}

RVD acknowledges DST-SERB for financial support in the form of Major research project No. SR/SO/AS-45/2011 and MSU-DBT-ILSPARE for infrastructural and technical support.

\section{References}

Belay A. The potential application of spirulina (arthrospira) as a nutritional and therapeutic supplement in health management. J Am Nutraceutl Assoc. 2002; 5: 26-48.

Bennet A, Bogorad L. Complementary chromatic adaptation in a filamentous blue-green algae. J Cell Biol. 1973; 58: 419-35.

Benzie IFF, Strain JJ. The ferric reducing ability of plasma (FRAP) as a measure of "antioxidant power": The FRAP assay. Anal Biochem. 1996; 239: 70-76.

Brekelman TR, Lagariaz JC. Visualization of bilin-linked peptides and proteins in polyacrylamide gels. Anal Biochem. 1986; 156: 194-201.

Devkar RV, Pandya AV, Shah NH. Protective role of Brassica olerecea and Eugenia jambolana extracts against $\mathrm{H}_{2} \mathrm{O}_{2}$ induced cytotoxicity in H9C2 cells. Food Function. 2012; 3: 37-43.

Elmore S. Apoptosis: A review of programmed cell death. Toxicol Pathol. 2007; 35: 495-516.

Gajaria TK, Patel DK, Devkar RV, Ramachandran AV. Flavonoid rich extract of Murraya Koenigii alleviates in-vitro LDL oxidation and oxidized LDL induced apoptosis in raw 264.7 Murine macrophage cells. J Food Sci Technol. 2015; 52: 3367-75.

Garfin D. One-dimensional gel electrophoresis. In: Guide to protein purification. Deutscher MP, Abelson JN, Simon MI, (eds). California, Academic Press, 1990, pp 425-41.

Huang B, Wang GC, Zeng CK, Li ZG. Experimental research of R-phycoerythrin subunits on cancer treatment: A new photosensitizer in PDT. Cancer Biother Radio. 2002; 17: 35-42.

Jiang X, Wang X. Cytochrome C-mediated apoptosis. Annu Rev Biochem. 2004; 73: 87-106.

Lowry HO, Rosenbrough NJ, Farr AL, Randall RJ. Protein measurement with the folin phenol reagent. J Biol Chem. 1951; 193: 265-75.

Madamwar D, Patel DK, Desai SN, Upadhyay KK, Devkar RV. Apoptotic potential of c-phycoerythrin from phormidium sp. A27DM and halomicronema sp. A32DM on human lung carcinoma cells. EXCLI J. 2015; 14: 527-39.

Pan Q, Chen M, Li J, Yan Wu, Zhen C, Liang B. Antitumor function and mechanism of phycoerythrin from Porphyra haitanensis. Biol Res. 2013; 46: 87-95.

Parmar A, Singh NK, Kaushal A, Sonawala S, Madamwar D. Purification, characterization and comparison of phycoerythrins from three different marine cyanobacterial cultures. Bioresource Technol. 2011; 102: 1795-802.
Patel D, Desai SN, Gajaria TK, Devkar R, Ramachandran AV. Coriandrum sativum L. seed extract mitigates lipotoxicity in raw 264.7 cells and prevents atherogenic changes in rats. EXCLI J. 2013;12: 313-34.

Patel DK, Desai SN, Gandhi HP, Devkar RV, Ramachandran AV. Cardio protective effect of Coriandrum sativum L. on isoproterenol induced myocardial necrosis in rats. Food Chem Toxicol. 2012; 50: 3120-25.

Ramadevi P, Singh R, Jana SS, Devkar R, Chakraborty D. Ruthenium complexes of ferrocene mannich bases: DNA/ BSA interactions and cytotoxicity against A549 cell line. J Photoch Photobio A. 2015; 305: 1-10.

Report on carcinogens. US Department of Health and Human Services, Public Health Service. National Toxicology Program, 2011, 12 iii-499.

Rito-Palomares M, Nunez L, Amador D. Practical application of aqueous two-phase systems for the development of a prototype process for c-phycocyanin recovery from Spirulina maxima. J Chem Technol Biot. 2001; 76: 1273-80.

Rodríguez-Sánchez R, Ortiz-Butrón R, Blas-Valdivia V, Hernández-García, A, Cano-Europa E. Phycobiliproteins or C-phycocyanin of Arthrospira (spirulina) maxima protect against $\mathrm{HgCl} 2$-caused oxidative stress and renal damage. Food Chem. 2012; 135: 2359-65.

Romay CH, González R, Ledón N, Remirez D, Rimbau V. Cphycocyanin: A biliprotein with antioxidant, anti-inflammatory and neuroprotective effects. Curr Protein Pept Sc. 2003; 4: 207-16

Sankhari JM, Thounaojam MC, Jadeja RN, Devkar RV, Ramachandran AV. Anthocyanin-rich red cabbage (Brassica oleracea L.) extract attenuates cardiac and hepatic oxidative stress in rats fed an atherogenic diet. J Sci Food Agric. 2012; 92: 1688-93.

Schmidt M, Bastians $H$. Mitotic drug targets and the development of novel anti-mitotic anticancer drugs. Drug Resist Update. 2007; 10: 162-81.

Shah V, Garg N, Madamwar D. Record of the marine cyanobacterium from the rocky shores of Bet-Dwarka and Okha, India. Acta Bot Malacit. 2001; 26: 188-93.

Singh NK, Parmar A, Madamwar D. Optimization of medium components for increased production of C-phycocyanin from Phormidium ceylanicum and its purification by single step process. Bioresource Technol. 2009; 100: 1663-69.

Singh R, Jadeja RN, Thounaojam MC, Devkar RV, Chakraborty D. Synthesis characterization DNA binding and cytotoxicity studies of moxifloxacinato complexes. Transit Metal Chem. 2012; 37: 541-51.

Soni B, Kalavadia B, Trivedi U, Madamwar D. Extraction, purification and characterization of phycocyanin from Oscillatoria quadripunctulata: Isolated from the rocky shores of Bet-Dwarka, Gujarat, India. Process Biochem. 2006; 41: 2017-23.

Thakore SI, Nagar PS, Jadeja RN, Thounaojam M, Devkar RV, Rathore PS. Sapota fruit latex mediated synthesis of $\mathrm{Ag}, \mathrm{Cu}$ mono and bimetallic nanoparticles and their in vitro toxicity studies. Arab J Chem. 2015. 
Valodkar M, Jadeja RN, Thounaojam MC, Devkar RV, Thakore S. In vitro toxicity study of plant latex capped silver nanoparticles in human lung carcinoma cells. Mater Sci Eng: C. 2011 ; 31: 1723-28.

Valodkar M, Rathore PS, Jadeja RN, Devkar RV, Thakore S. Cytotoxicity evaluation and antimicrobial studies of starch capped water soluble copper nanoparticles. J Hazard Mater. 2012; 201: 244-49.

Vyas KM, Jadeja RN, Patel D, Devkar RV, Gupta VK. Effect of ligand substitution in pyrazolone based binary and ternary $\mathrm{Cu}$ (II) complexes on DNA binding, protein binding and anticancer activity on A549 lung carcinoma cell lines.
Polyhedron 2014; 80: 20-23.

Vyas KM, Jadeja RN, Patel D, Devkar RV, Gupta VK. A new pyrazolone based ternary $\mathrm{Cu}$ (II) complex: Synthesis, characterization, crystal structure, DNA binding, protein binding and anti-cancer activity towards A549 human lung carcinoma cells with a minimum cytotoxicity to noncancerous cells. Polyhedron 2013; 65: 262-74.

Waterbury JB, Stanier RY. Isolation and growth of cyanobacteria from marine and hypersaline environments. In: The Prokaryotes. Starr MP Stolp H, Trüper HG, Balows A, Schlegel HG (eds). Berlin, Springer-Verlag, 1981, pp 221-23. 